\title{
MOTERŲ, SERGANČIŲ GIMDOS KAKLELIO VĖŽIU, SLAUGA
}

\author{
Giedrè Paulikaitè ${ }^{1}$, Lina Gedrimé $\dot{1}^{1}$, Artūras Razbadauskas ${ }^{2}$ \\ ${ }^{I}$ Klaipedos universiteto Sveikatos mokslu fakultetas, \\ ${ }^{2}$ Klaipédos jürininku ligonine
}

Raktažodžiai: gimdos kaklelio vėžys (GKV), slauga, komplikacijos, gimdos kaklelio vėžio gydymo metodai.

\section{Santrauka}

Darbo tikslas - išanalizuoti moterų, sergančių gimdos kaklelio véžiu (GKV), slaugą.

Tyrimas atliktas 2013-2015 metais. Taikyta apklausa atlikta raštu, užpildant anonimini klausimyną. Tyrimo kontingentą sudare neatsitiktinè imtis, kurioje buvo ịtrauktos ịvairios stadijos gimdos kaklelio věžiu sergančios ir besigydžiusios Klaipèdos miesto ligoninių pacientès. Savarankiškai sudarytu klausimynu buvo siekta įvertinti pacienčių slaugos poreikius atsižvelgiant ị esamą gimdos kaklelio vèžio stadiją ir taikytą gydymo metodą.

Rezultatai. Atliktame tyrime didžiają dalị apklaustujų sudarė 41-50 m. amžiaus respondentès. Nustatyta, jog sergančioms GKV, dažniausiai pasireiškia šie simptomai: skausmas, nuovargis ir pykinimas, o rečiausiai pasireiškiantys simptomai - vidurių užkietejjimas, šlapimo nelaikymas, burnos gleivinès išopejjimas. Dažniausi išreikšti slaugos poreikiai: slaugytojo buvimas šalia, atidus išklausymas reikalingas respondentems. Vyraujantis simptomasskausmas, kuriam pasireiškus iškyla didžiausias slaugytojo pagalbos poreikis.

Išvados. Sergančiųjų GKV slaugos poreikiai priklauso nuo stadijos, kurioje buvo diagnozuotas ir pradètas gydyti GKV bei taikyto gydymo metodo, nes po kiekvieno gydymo metodo pasireiškia skirtinga simptomatika, kuri reikalauja individualios ir lanksčios slaugos praktikos. Išryškèja respondenčių psichosocialiniai poreikiai, kurie parodo, jog medicinoje pacientai suvokiami kaip holistinè asmenybè.

\section{Ivadas}

Onkologinès ligos XXI amžiuje tampa vis dažnesne diagnoze. Tarp moterų labiausiai paplitęs sergamumas krūties, odos, gimdos kūno ir gimdos kaklelio piktybiniais navikais. Higienos instituto duomenimis, gimdos kaklelio vėžys - dažna moterų onkologinė liga Lietuvoje, kuri užima 3-4-tą vietą tarp piktybinių navikų, todèl šių ligų profilaktika ir gydymas tampa vis aktualesni ir labiau plètojami. Gimdos kaklelio vėžiu sergančiujų atvejų skaičius pastaruoju dešimtmečiu Lietuvoje yra ženkliai didesnis už tendencijas, vyraujančias Europoje, tai nulemia tik 2004 metais pradèta vykdyti Atrankines patikros dèl gimdos kaklelio patologijos programa, gerokai padidejo naujai nustatytų gimdos kaklelio vėžio atvejų skaičius, iš statistinių duomenų svyravimo galima spręsti, jog sergamumas gimdos kaklelio vėžiu nèra stabilus ir tampa vis dažnesne diagnoze [7]. Lietuvoje gimdos kaklelio vėžys- antra dažniausia 30-54 metų amžiaus moterų onkologinè liga, sudaranti net $14 \%$ visų piktybinių ligų šioje amžiaus grupeje[3]. Kiekviena liga išsiskiria specifišku gydymo, slaugymo metodu bei medicinos personalo pasiruošimu. Pagrindiniai gimdos kaklelio vėžio gydymo būdai: chirurginis gydymas, spindulinè terapija, chemoterapija bei mišrus gydymo metodų taikymas. Kiekvienas gydymo metodas skiriasi pritaikymo ir slaugymo metodika, kurią turi išmanyti medicinos personalas. Slaugytojas-tai medicinos personalo darbuotojas, kuris daugiausia laiko praleidžia su sergančiosiomis gimdos kaklelio vėžiu. Todèl slaugytojai turi būti pakankamai kvalifikuoti, kad sugebètų identifikuoti ir išspręsti kylančias slaugos problemas.

Darbo tikslas - išanalizuoti sergančiujų gimdos kaklelio vėžiu slaugą.

\section{Tyrimo medžiaga ir metodai}

Kiekybinis tyrimas atliktas 2013-2015 metais, kurio instrumentas yra panašių atliktų mokslinių tyrimų duomenimis, teorijoje išskirtais kriterijais, darbo autorès savarankiškai sukurtas originalus klausimynas, kuris analizuoja, kaip sergančiosioms skirtingomis GKV stadijomis taikyti gydymo metodai nulemia pacienčių slaugos poreikius. Tyrimo kontingentą sudarè neatsitiktinè imtis, ị kurią kitiems individams patekti tikimybé lygi nuliui. Kad būtụ išanalizuoti išsikelti uždaviniai tiriamąsias respondentes 
turèjo sieti požymiai: nustatyta gimdos kaklelio vėžio diagnozè, taikomas gydymas gimdos kaklelio véžiui Klaipèdos miesto ligoninèse bei gebejjimas suprasti informaciją lietuviškai, nes anketa parengta lietuvių kalba. Tyrimui atlikti buvo išdalinta 80 klausimynų atsitiktinai pasirinktoms respondentèms, sergančioms GKV, sugrižo $87,5 \%$, iš kurių tinkamai (visiškai) užpildyti 63 klausimynai, tai nulèmè tiriamujjų kontingento įvairovę: respondentès sirgo įvairių GKV stadijomis ir joms buvo taikyti skirtingi gydymo metodai. Gauti duomenys buvo susisteminami, analizuojami ir pateikiami diagramų ar lentelių pavidalu naudojantis Microsoft Office Excel 2007, bei Microsoft Word 2007 programomis.

\section{Rezultatai}

Respondenčių bendras amžiaus vidurkis 59,2 metai (amžiaus intervalas nuo 22 iki 89 metų). Siekiant išsiaiškinti, kokiame amžiaus tarpsnyje vyrauja didžiausias ligotumas GKV, respondentès buvo suskirstytos i amžiaus grupes kas 10 metų. 24\% apklaustujų buvo 41-50 metų am-

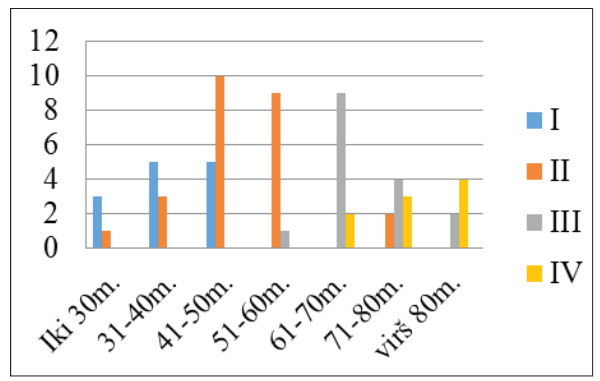

1 pav. GKV stadijų pasiskirstymas amžiaus grupėse 2pav. Taikytas gydymo būdas skirtingose GKV stadijose

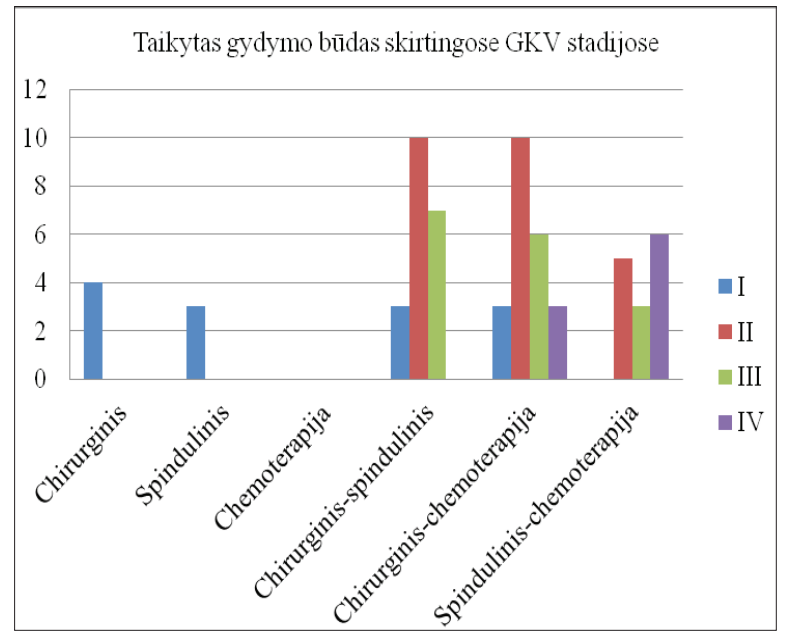

2 pav. Taikytas gydymo būdas skirtingose GKV stadijose žiaus ir tik $6 \%$ buvo iki $30 \mathrm{~m}$. (1 pav.).

Tyrimo eigoje buvo siekiama išsiaiškinti, kokioje stadijoje respondentėms buvo nustatytas GKV ir kokio amžiaus grupèse vyrauja skirtingų stadijų dažnis. Atliktame tyrime GKV didžiajai daliai (40\%) respondenčių buvo diagnozuotas II stadijoje, o mažiausiai (14\% respondentems) IV stadijoje, 21\% respondenčių I stadijoje, 25\% respondenčių - III stadijoje (2 pav.).

Tyrimo rezultatai parode, jog $-56(89 \%)$ respondentems buvo taikytas kombinuotas gydymas, o $11 \%$ taikytas vienas gydymo metodas. Mūsų tyrimų duomenimis, $6 \%$ iš $11 \%$ respondenčių, kurioms pritaikytas vienas gydymo metodas, buvo skirtas tik chirurginis gydymas. $21 \%$ respondenčių GKV buvo diagnozuotas I stadijoje, tačiau ankstyva diagnostika ne visada lèmé, jog respondentei buvo skiriamas tik vienas chirurginio ar spindulinio gydymo metodas, todèl buvo siekiama ištirti, kaip dažnai taikomi kombinuoti gydymo metodai respondentems ir koks jų pasiskirstymas esant skirtingoms GKV stadijoms. Dažniausiai 39\% respondenčių buvo taikomas chirurginis ir spindulinis gydymas II ir III GKV stadijoje (2 pav.).

Gauti rezultatai leidžia teigti, jog dažniausiai pasireiškiantis ir varginantis simptomas yra skausmas, kuris kartais (keletą kartų per savaitę) pasireiškia net $70 \%$ respondenčių, taip pat $17 \%$ respondenčių skausmas kamuoja nuolatos(kasdien), tik 13\% respondentès îvardijo, jog skausmo nejuto niekada. (3 lent.).Antras pagal pasireiškimo dažnumą yra nuovargis, kuris nuolatos kamuoja net 56\% respondenčių, o kartais (keletą kartų per savaitę) $37 \%$ respondenčių. Galima daryti prielaidą, jog nuolatos jaučiamą nuovargị nulemia ir dažnai pasireiškianti nemiga, kuri neleidžia tinkamai pailsèti ir atgauti jègas miego metu, nemiga nuolatos kamuoja 29\%, kartais (keletą kartu per savaitę) $56 \%$ respondenčių. Taip pat dažnai respondenčiu įvardijamas simptomas - pykinimas, kuris kartais (keletą kartų per savaitę) pasireiškia $68 \%$ respondenčių. Rečiausiai respondentems pasireiškẻ šie simptomai: vidurių užkietejimas - visada (kasdien) 5\%, kartais (keletą kartu per savaitę) $24 \%$, šlapimo nelaikymas - visada(kasdien) $5 \%$, kartais (keletą kartų per savaitę) $27 \%$, burnos gleivinès išopejimas - visada(kasdien) 13\%, kartais (keletą kartų per savaitę) $24 \%$, lytinès funkcijos sumažejjimas - visada (kasdien) 16\%, kartais (keletą kartų per savaitę) 33\%.

Respondentès ịvardijo, jog joms yra svarbiausia slaugytojo buvimas šalia, kai jos prastai jaučiasi: labai reikalinga nurode $45 \%$, reikalinga $40 \%$ apklaustujų. Kad labai reikalinga, jog slaugytojos atidžiai išklausytų ir suprastų jas, nurodo $38 \%$ pacientès, reikalinga $30 \%$ pacienčių. Šie duomenys parodo, jog respondentems pakankamai aktualus slaugytojo kaip pagalbininko vaidmuo. Taip pat res- 
3 lent. Simptomų pasireiškimo dažnis pacientėms po taikyto gydymo

\begin{tabular}{|c|c|c|c|c|c|c|}
\hline Simptomas & $\begin{array}{l}\text { Nie- } \\
\text { kada }\end{array}$ & & $\begin{array}{c}\text { Kartais } \\
\text { (keletą } \\
\text { kartų per } \\
\text { savaitę) }\end{array}$ & & $\begin{array}{c}\text { Visada } \\
\text { (kas- } \\
\text { dien) }\end{array}$ & \\
\hline & n & Proc. & n & Proc. & n & Proc. \\
\hline Skausmas & 8 & 13 & 44 & 70 & 11 & 17 \\
\hline Kraujavimas & 15 & 24 & 41 & 65 & 7 & 11 \\
\hline Pykinimas & 12 & 19 & 43 & 68 & 8 & 13 \\
\hline Vèmimas & 32 & 50 & 25 & 40 & 6 & 10 \\
\hline $\begin{array}{l}\text { Burnos gleivinès } \\
\text { išopéjimas }\end{array}$ & 40 & 63 & 15 & 24 & 8 & 13 \\
\hline Apetito stoka & 9 & 14 & 39 & 62 & 15 & 24 \\
\hline Svorio kritimas & 15 & 24 & 28 & 44 & 20 & 32 \\
\hline $\begin{array}{l}\text { Skausmingas šla- } \\
\text { pinimasis }\end{array}$ & 28 & 45 & 31 & 49 & 4 & 6 \\
\hline $\begin{array}{l}\text { Šlapimo nelaiky- } \\
\text { mas }\end{array}$ & 43 & 68 & 17 & 27 & 3 & 5 \\
\hline Viduriavimas & 41 & 65 & 18 & 29 & 4 & 6 \\
\hline $\begin{array}{l}\text { Vidurių užkietè- } \\
\text { jimas }\end{array}$ & 45 & 71 & 15 & 24 & 3 & 5 \\
\hline Plaukų slinkimas & 33 & 52 & 10 & 16 & 20 & 32 \\
\hline Nagų lūžinèjimas & 23 & 37 & 21 & 33 & 10 & 16 \\
\hline $\begin{array}{l}\text { Lytinès funkcijos } \\
\text { sumažejimas }\end{array}$ & 32 & 51 & 21 & 33 & 10 & 16 \\
\hline Nemiga & 10 & 16 & 35 & 56 & 18 & 29 \\
\hline Nuovargis & 5 & 8 & 23 & 37 & 35 & 56 \\
\hline Silpnumas & 6 & 10 & 28 & 44 & 29 & 46 \\
\hline Apatiškumas & 7 & 11 & 41 & 65 & 15 & 24 \\
\hline
\end{tabular}

pondentès ịvardijo, jog joms svarbi slaugytojo pagalba padedant kontroliuoti skausmo pasireiškimą: labai reikalinga 32\%, reikalinga 35\% (4 lent.) Gautais duomenimis, mažiausias slaugos poreikis ryškus respondenčių savarankiškumo srityje: padedant pacientèms apsirengti, labai reikalinga pagalba tik $8 \%$, reikalinga $5 \%$ respondentems, taip pat nežymus pagalbos poreikis padedant susišukuoti: labai reikalinga $8 \%$, reikalinga $10 \%$ respondenčių. Taip pat mažiausiai slaugytojų pagalbos reikia burnos išopejjimo atveju, kuris ịvardijamas kaip vienas iš simptomų, pasireiškiantis nuolatos (kasdien) 13\% ir kartais (keletą kartų per savaitę) $24 \%$ respondenčiu, todèl suprantama, kad ir slaugos poreikis esant burnos gleivinès išopejimui pasireiškia nedidelei daliai respondenčių: labai reikalinga $13 \%$, reikalinga $8 \%$.

Respondentès geriausiai vertina slaugytojo, kaip informacijos teikejjo, vaidmenį, nes $24 \%$ respondenčių visiškai sutinka ir $56 \%$ respondenčių sutinka, jog slaugytojas suteikia aiškią ir suprantamą informaciją apie vykdomus slaugos veiksmus. Taip pat didelè dalis respondenčių teigiamai ịvertina slaugytojų sugebejimą tinkamai atsakyti $i$ užduodamus klausimus: visiškai sutinka $37 \%$, sutinka $49 \%$ respondenčių, 54\% respondenčių patenkintos slaugytojų pateikiamos informacijos suprantamumu, respondentèms mažiausiai pagalbos buvo suteikta esant vidurių užkietè- jimo problemoms: visiškai sutinka, jog pagalba suteikta tik $8 \%$ ir sutinka $13 \%$ respondenčių, tačiau svarbu atsižvelgti i tai, jog net $71 \%$ respondenčių vidurių užkietejjimas nepasireiškè, tokia pati situacija ir su burnos gleivinès išopejimu, pasireiškimo dažnis mažas, todèl respondentès negali įvertinti, kaip slaugytoja padètu pasireiškus šiam simptomui.

Atliekamo tyrimo metu buvo norima sužinoti, kaip respondentès vertina slaugytojo veiklos kokybę. Mažiausias balas, kuris buvo skirtas slaugytojo veiklos kokybei įvertinti, buvo 6 (patenkinamai). Jị skyrè 5\% respondenčių, o aukščiausias balas buvo 10 (puikiai) 19\% respondenčių, tačiau dažniausiai veikla buvo įvertinama 9 (labai gerai) balais. Šị vertinimą pažymėjo 37\% respondenčių. Slaugytojų veiklos kokybès vertinimo vidurkis 10 balų sistemoje $-8,746$ balo.

\section{Rezultatų aptarimas}

Atliktame tyrime didžiają dali (24\%) apklaustujų sudarè 41-50 m. Kaip ir nagrinètoje literatūroje $[5,6]$ teigiama, jog pirmieji GKV požymiai dažniausiai pasireiškia 40-50 m. moterims, jaunesnis sergančiųjų amžius nurodo ligos aktualumą ir nepavėluotos diagnostikos svarbą.

Pagal ịgyto išsilavinimo lygi pastebèta, jog tai svarbus rodiklis ankstyvai GKV diagnostikai, 5 iš 8 respondenčių, turinčioms universitetinị išsilavinimą, gimdos kaklelio vèžys buvo diagnozuotas I stadijoje, o respondentems, turinčioms žemesnį išsilavinimą (vidurinį išsilavinimą), GKV buvo diagnozuotas vèlyvesnèse stadijose: $14 \%$ respondenčių III stadijoje ir 13\% respondenčių IV stadijoje. Respondenčių igytas aukštesnis išsilavinimas nulemia sveikatos raštingumą bei rūpinimąsi ja, dalyvavimą profilaktinèse programose, kurios padidina ankstyvos diagnostikos rodiklius, tai atitinka [4] atlikto tyrimo duomenis, jog išsilavinimas tiesiogiai nulemia respondenčių dalyvavimą profilaktinèse sveikatos patikros programose, nes net $61,1 \%$ respondenčių, neturinčių vidurinio išsilavinimo, nebuvo atliktas citologinio tepinèlio tyrimas.

GKV ligotumo rodikliai yra kur kas aukštesni tarp kaimo vietovėse gyvenančių respondenčių [2]. Atlikto tyrimo metu respondenčiu skaičiaus skirtumas pagal gyvenamają vietą nėra ženklus: didmiestyje ir miestuose, kur gydymo instaigos lengviau pasiekiamos, gyvena $52 \%$, o kaimo vietovèse ir gyvenvietėse, kur šis prieinamumas blogesnis, $48 \%$ respondenčių. Pagal šeiminị statusą 56\% respondenčių atsake, jog yra vienišos (našlè, išsituokusi, netekejjusi), o 44\% yra ištekejjusios/bendrai gyvenančios nesusituokusios. „Antrają pusę“ turinčios respondentès lengviau susitaiko su nustatyta diagnoze bei sveikimo ir išgyvenamumo rodikliai yra aukštesni[1].

Atlikto tyrimo duomenimis išsiaiškinta, jog responden- 
4 lent. Slaugos poreikių pasiskirstymas

\begin{tabular}{|c|c|c|c|c|c|c|c|c|}
\hline \multirow[t]{2}{*}{ Slaugos poreikiai } & \multicolumn{2}{|c|}{$\begin{array}{c}\text { Visiškai } \\
\text { nereika- } \\
\text { linga }\end{array}$} & \multicolumn{2}{|c|}{$\begin{array}{l}\text { Ne- } \\
\text { reika- } \\
\text { linga }\end{array}$} & \multicolumn{2}{|c|}{$\begin{array}{l}\text { Rei- } \\
\text { kalin- } \\
\text { ga }\end{array}$} & \multicolumn{2}{|c|}{$\begin{array}{l}\text { Labai } \\
\text { reika- } \\
\text { linga }\end{array}$} \\
\hline & $\mathrm{n}$ & Proc. & $\mathrm{n}$ & Proc. & $\mathrm{n}$ & Proc. & n & Proc. \\
\hline $\begin{array}{l}\text { Man reikèjo nuolatinio } \\
\text { slaugytojo buvimo šalia, kai } \\
\text { blogai jaučiausi }\end{array}$ & 2 & 3 & 8 & 13 & 25 & 40 & 28 & 45 \\
\hline $\begin{array}{l}\text { Man reikėjo slaugytojo pagal- } \\
\text { bos esant pykinimui }\end{array}$ & 15 & 24 & 23 & 37 & 10 & 16 & 15 & 24 \\
\hline $\begin{array}{l}\text { Man reikèjo slaugytojo pagal- } \\
\text { bos esant silpnumui }\end{array}$ & 8 & 29 & 30 & 48 & 10 & 16 & 5 & 8 \\
\hline $\begin{array}{l}\text { Man reikėjo slaugytojo pa- } \\
\text { galbos esant burnos gleivinès } \\
\text { išopejimui }\end{array}$ & 35 & 56 & 15 & 24 & 5 & 8 & 8 & 13 \\
\hline $\begin{array}{l}\text { Man reikejo slaugytojo pagal- } \\
\text { bos gerinant miego kokybę }\end{array}$ & 20 & 32 & 11 & 17 & 22 & 35 & 10 & 16 \\
\hline $\begin{array}{l}\text { Man reikèjo slaugytojo } \\
\text { pagalbos esant vidurių už- } \\
\text { kietejimui }\end{array}$ & 15 & 24 & 34 & 52 & 10 & 16 & 4 & 6 \\
\hline $\begin{array}{l}\text { Man reikèjo slaugytojo pagal- } \\
\text { bos esant viduriavimui }\end{array}$ & 10 & 16 & 31 & & 17 & 27 & 5 & 8 \\
\hline $\begin{array}{l}\text { Man reikėjo slaugytojo } \\
\text { pagalbos padedant išspręsti } \\
\text { šlapinimosi problemas }\end{array}$ & 12 & 19 & 16 & 25 & 20 & 32 & 15 & 24 \\
\hline $\begin{array}{l}\text { Man reikèjo slaugytojo pagal- } \\
\text { bos maitinimosi metu }\end{array}$ & 15 & 24 & 25 & 40 & 13 & 21 & 10 & 16 \\
\hline $\begin{array}{l}\text { Man reikèjo slaugytojo pagal- } \\
\text { bos kontroliuojant skausmą }\end{array}$ & 4 & 6 & 6 & 10 & 22 & 35 & 20 & 32 \\
\hline $\begin{array}{l}\text { Man reikèjo slaugytojo pagal- } \\
\text { bos padedant nusiprausti }\end{array}$ & 20 & 32 & 27 & 43 & 9 & 14 & 7 & 11 \\
\hline $\begin{array}{l}\text { Man reikèjo slaugytojo pagal- } \\
\text { bos padedant susišukuoti }\end{array}$ & 25 & 40 & 27 & 43 & 6 & 10 & 5 & 8 \\
\hline $\begin{array}{l}\text { Man reikėjo slaugytojo pagal- } \\
\text { bos padedant apsirengti }\end{array}$ & 30 & 48 & 25 & 40 & 5 & 8 & 3 & 5 \\
\hline $\begin{array}{l}\text { Man reikèjo slaugytojo } \\
\text { nuraminimo esant išvaizdos } \\
\text { pokyčiams }\end{array}$ & 10 & 16 & 18 & 29 & 15 & 24 & 20 & 32 \\
\hline $\begin{array}{l}\text { Man reikèjo, kad slaugytoja } \\
\text { atidžiai išklausytų ir suprastų } \\
\text { mane }\end{array}$ & 10 & 16 & 10 & 16 & 19 & 30 & 24 & 38 \\
\hline $\begin{array}{l}\text { Man reikèjo, kad slaugytoja } \\
\text { užtikrintų privatumą }\end{array}$ & 13 & 21 & 16 & 25 & 24 & 35 & 10 & 16 \\
\hline $\begin{array}{l}\text { Man reikèjo, kad slaugytoja } \\
\text { atsakytų i iškylančius klausi- } \\
\text { mus apie slaugą, ligą }\end{array}$ & 8 & 13 & 20 & 32 & 20 & 32 & 15 & 24 \\
\hline $\begin{array}{l}\text { Man reikèjo, kad slaugytoja } \\
\text { suprantamai pateiktų infor- } \\
\text { maciją }\end{array}$ & 6 & 10 & 8 & 13 & 26 & 41 & 23 & 37 \\
\hline $\begin{array}{l}\text { Man reikejo, kad slaugytoja } \\
\text { suteiktų informaciją apie vyk- } \\
\text { domus slaugos veiksmus }\end{array}$ & 16 & 25 & 20 & 32 & 18 & 29 & 9 & 14 \\
\hline $\begin{array}{l}\text { Man reikèjo, kad slaugytoja } \\
\text { informuotų apie galimas } \\
\text { komplikacijas po pritaikytų } \\
\text { gydymo metodų }\end{array}$ & 7 & 11 & 4 & 6 & 25 & 40 & 17 & 27 \\
\hline $\begin{array}{l}\text { Man reikëjo, kad slaugytoja } \\
\text { suteiktų konsultaciju/reko- } \\
\text { mendacijų apie laikotarpi po } \\
\text { gydymosi stacionare }\end{array}$ & 13 & 21 & 15 & 24 & 15 & 24 & 20 & 32 \\
\hline
\end{tabular}

tėms, sergančioms GKV, dažniausiai pasireiškia šie simptomai: skausmas $87 \%$, nuovargis $56 \%$ ir pykinimas $68 \%$, o rečiausiai pasireiškiantys simptomai - vidurių užkietejjimas $5 \%$ ir šlapimo nelaikymas 5\%, burnos gleivinès išopejjimas nuolatos $13 \%$. Ivardijamais duomenimis nustatant diagnozę, skausmas gali varginti $20-50 \%$ ligonių[6], 50\% pacientų skundžiasi skausmais gydymo metu, o ligai progresuojant skausmus kenčia 75-90\% ligonių [10].

Taip pat didele dalis respondenčių teigiamai ịvertina slaugytojų sugebejjimą tinkamai atsakyti ị užduodamus klausimus: visiškai sutinku $37 \%$, sutinku $49 \%$ respondenčių, $54 \%$ respondenčiu patenkintos slaugytojų pateikiamos informacijos suprantamumu. Šie gauti duomenys parodo, jog šioje srityje slaugytojo veiklos kokybè tapo kur kas geriau vertinima ir patobulèjo, nes analizuotoje mokslinèje literatūroje pabrěžiamas slaugytojo kaip mokytojo vaidmens reikalingumas, ir kad tai dar tebèra siekiamybè. Tyrimo duomenimis, apklausiant slaugytojus apie jų žinių pakankamumą teikti informaciją pacientams, ịvardijama, jog trys ketvirtadaliai slaugytojų mano, kad jiems tik dalinai pakanka žinių apie sveikatos mokymą, taip pat atkreipiamas dèmesys, jog savo žinias geriau vertino slaugytojai, turintys aukštaji nei aukštesniji išsilavinimą [9].

Sergančiųjų GKV slaugos poreikiai priklauso nuo stadijos, kurioje buvo diagnozuotas ir pradètas gydyti GKV bei taikyto gydymo metodo, nes po kiekvieno gydymo metodo pasireiškia skirtinga simptomatika, kuri reikalauja individualios ir lanksčios slaugos praktikos. Tobulèjant medicinai jaučiamas poreikis ir slaugos personalo tobulinimuisi, nes gerinamas slaugos procesas lemia palankesnes sveikimo baigtis bei 
geresnę pacienčių savijautą. Išryškèja pacienčių psichosocialiniai poreikiai, kurie parodo, jog medicinoje pacientai suvokiami kaip holistinè asmenybè.

\section{Išvados}

1. Atlikto tyrimo duomenimis išsiaiškinta, jog respondentèms, sergančioms GKV, dažniausiai pasireiškia šie simptomai: skausmas, nuovargis, pykinimas, o rečiausiai pasireiškia vidurių užkietėjimas ir šlapimo nelaikymas, gleivinès išopejjimas.

2. Analizuojant slaugos poreikius, nustatyta, kad labiausiai respondentems reikalingas slaugos poreikis šiose srityse: slaugytojo buvimas šalia, atidus išklausymas, pagalba kontroliuoti skausmą. Mažiausiai ryškus slaugytojo pagalbos poreikis, kai kalbama apie savarankiškumą bei judejjimo laisvę: pagalba apsirengiant, pagalba susišukuojant. Atlikto tyrimo metu taip pat pastebèta, jog nėra tiesioginio ryšio tarp simptomų pasireiškimo dažnumo ir pagalbos reikalingumo pasireiškimo: silpnumą jautimo ir slaugos poreikio ji kontroliuoti, skausmo jautimo ir slaugytojo pagalbos poreikio ji kontroliuoti.

3. Slaugytojo veiklos kokybę respondentès vidutiniškai 10 balų sistemoje įvertino 8,746 balais. Respondentès geriausiai vertina slaugytojo kaip informacijos teikèjo vaidmenį: slaugytojas suteikia aiškią ir suprantamą informaciją apie vykdomus slaugos veiksmus, slaugytojai sugeba tinkamai atsakyti ị respondenčių užduodamus klausimus. Daugiau nei pusė atsakiusiujų nurodo, jog suteikta informacija yra suprantama. Mažiausiai respondenčių ịvertino slaugytojų atliktus veiksmus tinkamai padedant spręsti vidurių užkietėjimo problemas.

\section{Literatūra}

1. Amšiejienė A., Usoniene A., Šiaudinytė I.. Onkologiniu pacientu vaisingumo išsaugojimas. Lietuvos chirurgija, 2014; 13(1):46-51.

2. Dagienė R., Vaitkaitienė E.. Pacientų, susirgusių onkologine liga, darbingumo, gydymo savalaikiškumo ir teikiamų paslaugu subjektyvus vertinimas. KMU, 2011.

3. Daukantienė L., Schveigert D., Kinderytė E., Fadejeva J., Didžiapetrienè J. Glutationo S-transferazès genų polimorfizmas ir gimdos kaklelio vèžys. Labaratorinè medicina, 2014; 16(2):63-67.

4. Griškonis S., Stukčinskienė B., Doroškina J., Jurgutis A.. Moterų dalyvavimo gimdos kaklelio vėžio patikros programoje aspektai Klaipedos mieste. Sveikatos mokslai, 2009; 4:24612465.

5. Skvarciany Z. Darbingo amžiaus asmenų, sergančiųjų piktybiniais navikais, neigalumas bei su sveikata susijusi gyvenimo kokybė. Daktaro disertacija, Vilnius, 2012.

6. Karimi-Zarchi M, Mousavi A, Gilani MM, Barooti E, Miratashi-Yazdi A, Dehghani A. Conservative treatment in early cervical cancer. International Journal of Biomedical science 2013; 3:123-128.

7. Michael J., Gallagher M. R. Lètinis ir onkologinis skausmas. Vilnius. Nacionalinis medicinos mokymų centras, 2011; 92.

8. Ulinskas K. Veiksniai, lemiantys onkologinių ligonių išgyvenamumą. Medicinos teorija ir praktika, 2012; 18(2):236-242.

9. Zagurskienė D., Misecičienė I. Slaugytojų nuomonė apie pacientų sveikatos mokymą ir savo žinių sveikatos klausimais vertinimą. Sveikatos mokslai, 2011; 5:191-195.

10. Žemaitytė I., Gudaitytè J. Pacientu, sergančiụų onkologinèmis ligomis, žinios apie chemoterapijos šalutinị poveikị ir jo valdymą. Lietuvos sveikatos mokslų universiteto leidybos namai, 2012.

\section{WOMEN WITH CERVICAL CANCER NURSING CARE}

\section{G. Paulikaitè, L. Gedrimè, A. Razbadauskas}

Key words: cervical cancer nursing, cervical cancer treatment methods, care, complications.

\section{Summary}

The aim of the analysis of women with cervical cancer nursing care.

The study was conducted in 2013-2015. Applied survey conducted in writing, by filling the anonymous questionnaire. The study consisted of not accidental taking contingent, which were included: womens with vorious stages of cervical cancer, having treatment at Klaipedos city hospitals. The aim of self-composed questionnaire was to find out the care needs of patients with various stages of cervical cancer and different treatment method.

Results. In study find out that biggest respondents group is 41 50 olds. Respondents ansvered that mostly felt symptoms: pain, fatigue and nausea, while sparsely occuring symptoms: constipation, urinary incontinence, mouth ulceration. The mostly expresed care needs: the presence of a nurse near, attentitive hearing is reguired for respondents. The predominant symptom-pain, wich need the most assistence as a nurse.

Conclusions. Cervical cancer patients nursing needs depends on the stage, which was diagnosed and started treatment of cervical cancer and each treatment method affects different symptoms, wich reguires individual and flexible nursing practice. There appear psychosocial needs, wich shows that the medicine patients are perceived as a holistic personality.

Correspondence to: charizmatiskumas@gmail.com

$$
\text { Gauta 2016-11-16 }
$$

